\title{
Emerging trends of rainbow trout (Oncorhynchus mykiss) aquaculture in Nepal Himalaya
}

\author{
Tek Bahadur Gurung ${ }^{1 *}$, Suresh Kumar Wagle ${ }^{1}$, Agni Prasad Nepal ${ }^{1}$ and Gopal Prasad \\ Lamsal $^{2}$ \\ ${ }^{I}$ Nepal Agricultural Research Council \\ ${ }^{2}$ Fisheries Research Station, Trishuli \\ *E-mail: tek_fisheries@hotmail.com
}

\begin{abstract}
Recently, aquaculture technology of cold water Rainbow trout (Oncorhynchus mykiss) has been popular among farmers in hills and mountains of Nepal Himalaya. Production of rainbow trout started in government and private farms in 1995 and 1998, respectively. At present the rainbow trout farming has expanded in several mountain districts with rapidly growing demand in others adjacent areas. The total farmers have increased from none to 85 producing more than 180 metric ton from 16 districts by employing about 550 people in year 2012. The trout aquaculture technology could be expanded in areas having pristine, cold and clean water resources having road access for market destinations close to urban areas of all Trans Himalayan countries as a means to food and nutritional security, and employment opportunities in mountainous regions.
\end{abstract}

Key words: Rainbow trout, feed, cold water fish, growth trends

\section{Introduction}

The Himalayas offer excellent opportunities to develop cold water aquaculture as many glaciers, rivers, tributaries, lakes of mid hill and mountain provide high quality pristine waters. To utilize such abundant water resources rainbow trout (Oncorhynchus mykiss), sockeye salmon $(O$. nerka) and brown trout (Salmo trutta) having food and sport values were introduced earlier in Nepal (Gurung, 2010). However, those all attempts failed, probably due to inadequate technical knowhow, care and facilities such as raceways (flowing water fish holding system and feeds) for rearing (Swar, 2008). Later, 50,000-eyed eggs of rainbow trout (O. mykiss) were brought from Japan in 1988 as souvenir and token of friendship between Miyazaki Prefecture, Japan and Nepal (Nakagawa, 1998; Yamada et al., 1998; Gurung and Basnet, 2003). The eggs were successfully hatched and reared in Nepal. The rainbow trout farming technological packages after comprehensive research, testing, refinement, and innovation in Nepalese agroecological conditions were developed under Nepal Agricultural Research Council. The rainbow trout suited well in Nepal Himalaya, demonstrating that trout is a hardy fish and suitable for cultivation in cold waters. Now the trout is contributing in productivity enhancement of hill and mountain agricultural sector (Joshi \& Lofvall, 1997; Gurung et al., 2008; Voorhees, 2011). It is likely that rainbow trout farming offer substantial opportunities of food and nutrition security in hills and mountains through job and income opportunities. At present, the success of rainbow trout farming has been distinctly visible in terms of fish production, income and increasing income flow to rural hills from urban areas in wider parts of the Himalayan highlands. Thus, the objective of present paper is to elucidate the emerging trends of rainbow trout farming adoption using information on present status for further scaling up in wider areas in Nepal Himalaya. 


\section{Rainbow trout farming technological package development}

Rainbow trout attains approximately 200-300 g individual body weight in a year in aquaculture practices in Nepal (Nepal et al., 2002). The trout requires clean, high dissolved oxygen containing cold water for farming in high densities about 75 or more fish per $\mathrm{m}^{2}$ with high production rate of about $10-15 \mathrm{~kg}^{-1} \cdot \mathrm{m}^{-2} \cdot \mathrm{y}^{-1}$ highly depending on quality of seed, feed and water used. Initially, Nepal Agricultural Research Council (NARC) scientists carried out research activities on rainbow trout; as a result series of selection based activities were performed in order to develop viable production and breeding technologies (Voorhees, 2011; Gurung, 2010; Rai et al., 2005). Later, a package of practices on breeding, nursing and cultivation of trout, including feed formulation using locally available feed ingredients was developed for practical and cost effective farming in prevailing socio-economical situation.

Earlier all selection, breeding, larval rearing and nursing practices were exclusively carried out in research farms for fry production to support private farmers. However, the demand of fry increased with the increasing private trout farms entrepreneurs. To insure the adequate supply of fry, participatory breeding and nursing activities were carried out with private farmers. Similar participatory approach for pellet mill assemblage, feed formulation and production in farmer's farm was also adopted. As a result, the dry pellet feed machine started to be assembled in local workshops using locally available mechanical tools and accessories. In addition to innovative practices of constructing the raceway ponds along the shape of hill landscape by farmers themselves after having ideas of water exchange system for trout cultivation.

The trout farming has also been integrated with pico hydropower generation, resort, livestock, floriculture (Lamsal et al., 2008). Integrated approach of rainbow trout farming has created additional attraction in mountain slopes. The trout farming is economically viable practices (Nepal et al., 2002; Voorhees, 2011) as trout production rate ranges from $15-20 \mathrm{~kg} \cdot \mathrm{m}^{-2}$. Now the rainbow trout farming cultivation in private sector has been extended in 16 hill and mountain districts of Nepal Himalaya (Figure 1). Rainbow trout is one of the well studied fish of the world (Elizabeth et al., 2014), therefore to be competitive in world market more advanced research would be desirable in future in Nepal as well.

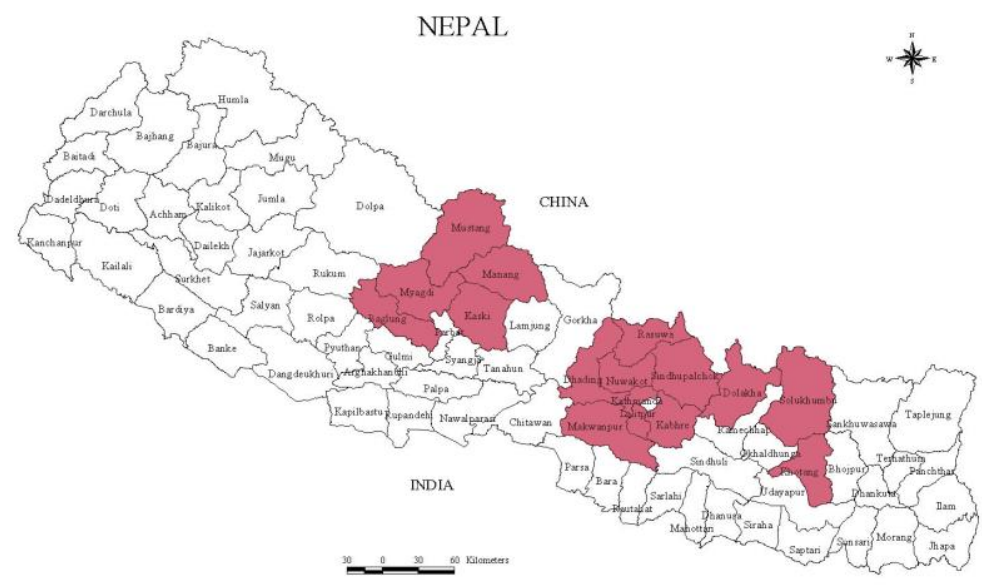

Figure 1. Location of districts where recently rainbow trout (O. mykiss) farming has been expanded 


\section{Status and emerging trends}

\section{Rural trout hatchery and fry production}

To expand the breeding program for supplying trout fry to farmers, a short term follow-up cooperation from Japan International Cooperation Agency (JICA) was started in 2007 for 4 months. The main objective of the support was strengthening trout seed supply through participatory breeding program. To encourage the farmers in trout breeding and fry production, an innovative approach was initiated, under which mature trout broods were sold to farmers for seed production. This program gained the popularity and motivated the farmers to enter directly into the business of trout fry production. Various stakeholders associated with trout farming were also trained for better technological, managerial and marketing aspects. At the beginning 3 hatcheries were supported. Presently, there are 12 rural hatcheries trout fry (Figure 2).

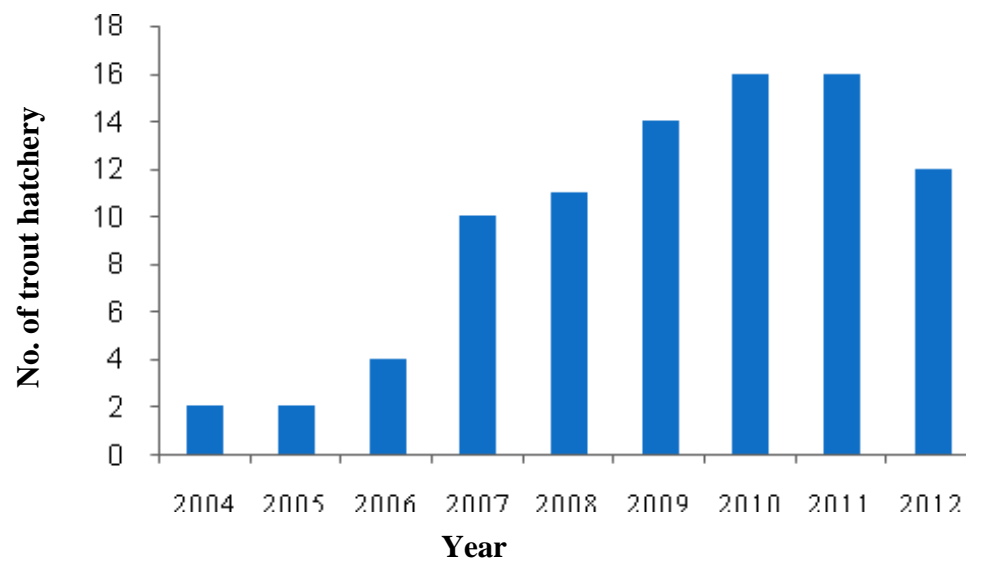

Figure 2. Number of rainbow trout hatcheries.

In these rural hatcheries about 18 million alevin were produced in year 2012, out of which 1.1 million fry survived, suggesting that there is still need to improve fry survival (Figure 3).

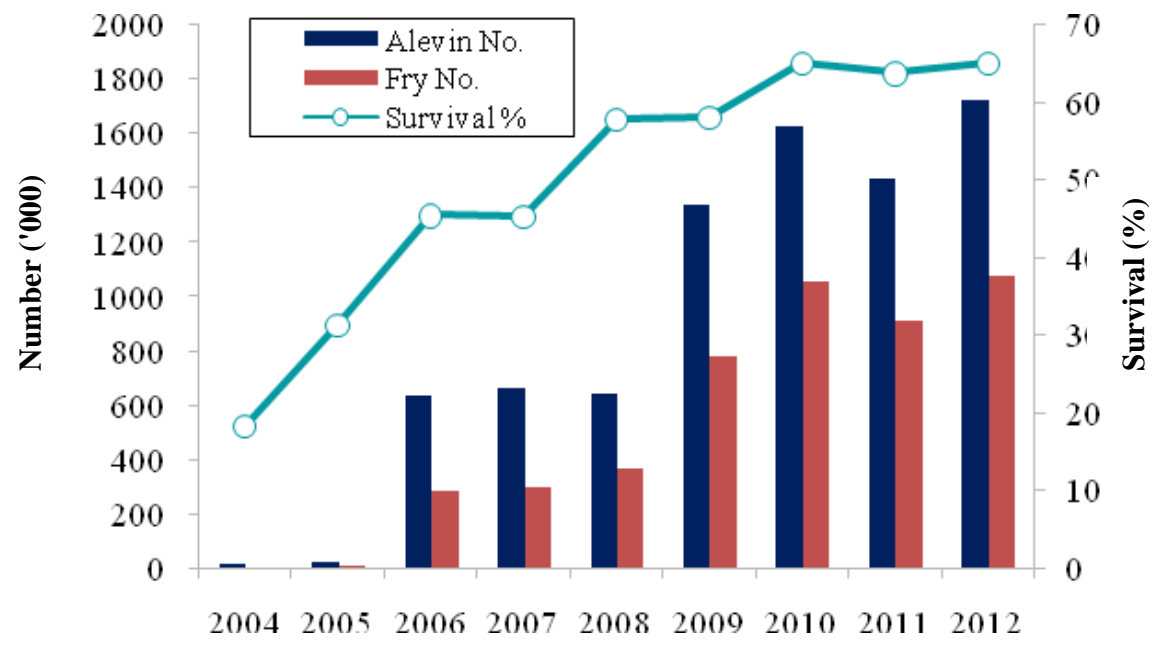

Figure 3. Survival trends of rainbow trout alevin to fry stage in Nepal 


\section{Feed}

The rainbow trout are carnivorous, thus requires high animal protein containing diets. In general, the protein level should be above 35\%, especially for broods and fry stage trout. The amount of diets depends on the size and life stages. The feed conversion ratio (FCR) highly depends on the quality of feed. In general, the present FCR in Nepal is approximately 2.5:1. However, recent studies have claimed that the FCR in trout can be reduced to 1:1.14 by improving the quality of feed and others (Shahrzad et al., 2013). Trout (O. mykiss) exclusively depend on external feed from the time larvae commence first feeding. Thus, the success of trout farming enterprise highly depends on quality of the feed. To make the trout farming successful in prevailing socio-economical situation following steps were taken:

i) Local resources such as liver meat available were successfully used as an alternative at the beginning. Later, pellet mills purchased by Aquaculture Development Project (ADB funded) produced pellet feed.

ii) More comprehensive feed formulation and production was started since 1995 with the assistance of Natural Water Fisheries Development Project (NWFDP) funded by Government of Japan.

iii) The feed technology was disseminated among small scale trout farmers.

iv) Using the pellet feed technology developed by NARC; Directorate of Fisheries Development (DOFD) supported one of the private sector entrepreneurs for sale to small scale trout farmers.

v) Now, the Government has also providing Grant assistance on competition basis to trout cooperatives for commercializing production through the Project for Agricultural Commercialization and Trade (PACT) supported by World Bank.

At present the total amount of trout feed produced (in year 2012) has reached approximately $427 \mathrm{mt}$ produced from 12 rural small scale feed plants operated by farmers themselves except few (Figure 4).

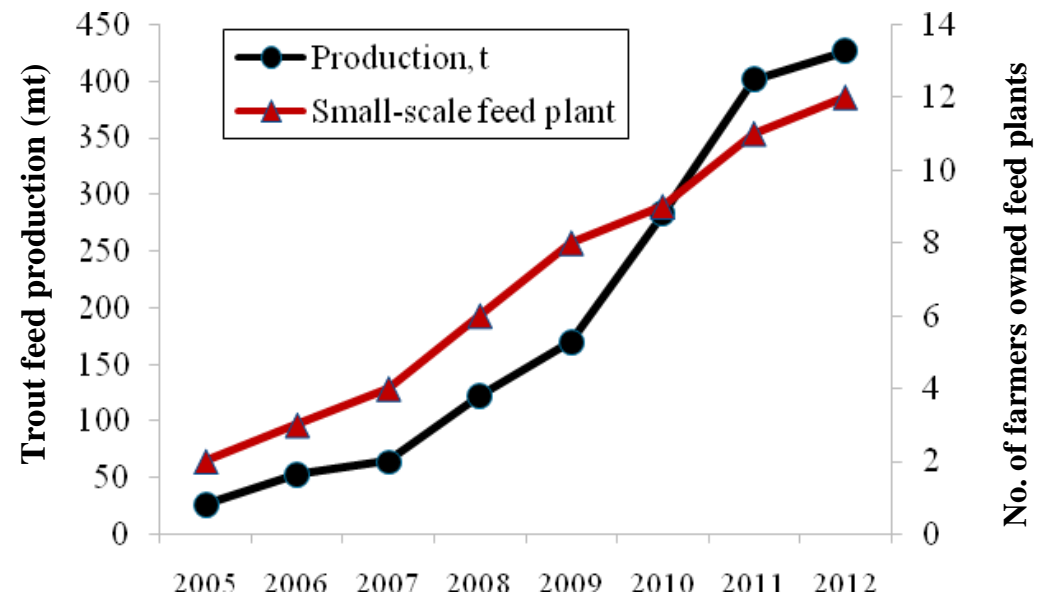

Figure 4. Trout feed production by farmers owned small scale feed plants 


\section{Area coverage and present trout production}

There are 85 private trout farms established in 16 districts covering an area of $13161 \mathrm{~m}^{2}$ producing about $180 \mathrm{mt}$ trout in 2012 (Figure 5). Mostly the trout raceways are constructed in sloppy land, where in general other agricultural crops are not grown. Besides, that fallow lands close to rivers and streams banks have also been useful for raceways construction for trout production. But, care should be taken to that flood and landslides would not harm fish farm.
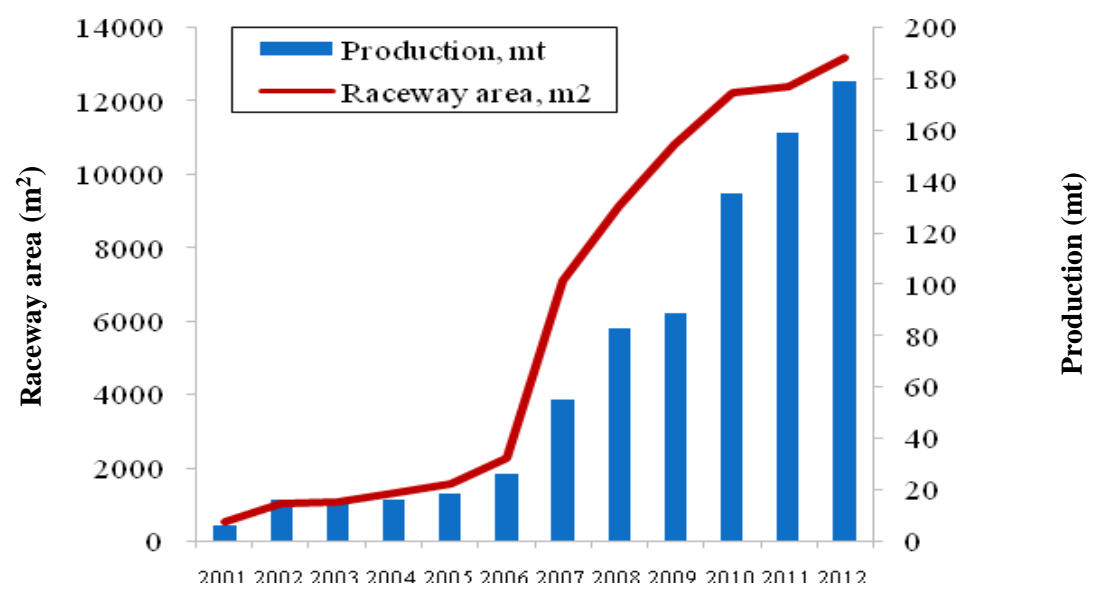

Figure 5. Raceway area and trout production in Nepal Himalaya.

At present the raceways are constructed using cement due to available landscape for trout aquaculture. This has increased the capital cost investment in trout farming. Further research is needed to find out cheaper ways for trout farm infrastructure to reduce the capital cost in trout farming. Rainbow trout can be cultivated in earthen ponds; however, the only requirement of water flow should be maintained. Major parts of Nepal are hills and mountains with abundant cold water resources, therefore assumed to be highly potential for cold water aquaculture development (Rajbanshi, 2002; Swar, 2002). It is expected that the rainbow trout farming technology would be further expanded in other areas soon including the whole upper regions of the Himalayan countries.

\section{Marketing and social contribution}

With successful achievements of trout production market outlets were created. For the purpose market survey were carried out and efforts were made to popularize the rainbow trout dishes in hotels, restaurants, department stores targeting on general consumers. Public demonstrations of cooking and preparation of trout delicacy were also launched in various exhibitions. Recipes were published for distribution. At present rainbow trout is one of the favorite dishes in hotels and restaurants (Shrestha, 2008).

In 2006 Government of Nepal declared two adjacent districts close to the capital city, Kathmandu, as trout growing districts under 'One village One Product' (OVOP) program where trout farming was prioritized to promote the local farmers by using cold water resources and local tourism with Public-Private-Partnership (PPP). 
Under this, experts from Nepal Agricultural Research Council (NARC) and private sector Agro Enterprise Centre (AEC) of Federation of Nepalese Chamber of Commerce and Industry (FNCCI) worked together for promotion of trout. Public sector was responsible for technical backstopping and extension services required for enhancing trout production in private sector, while AEC was responsible in motivating the local entrepreneurs and communities by modern processing, packaging, distribution system, and effective marketing programs. This program was designed for 3 years from 2006 to 2009 . Under the scaling up of the trout farming technology verification of brood management, breeding, seed transportation, rearing and nursing, feed, health and local resource management were prioritized.

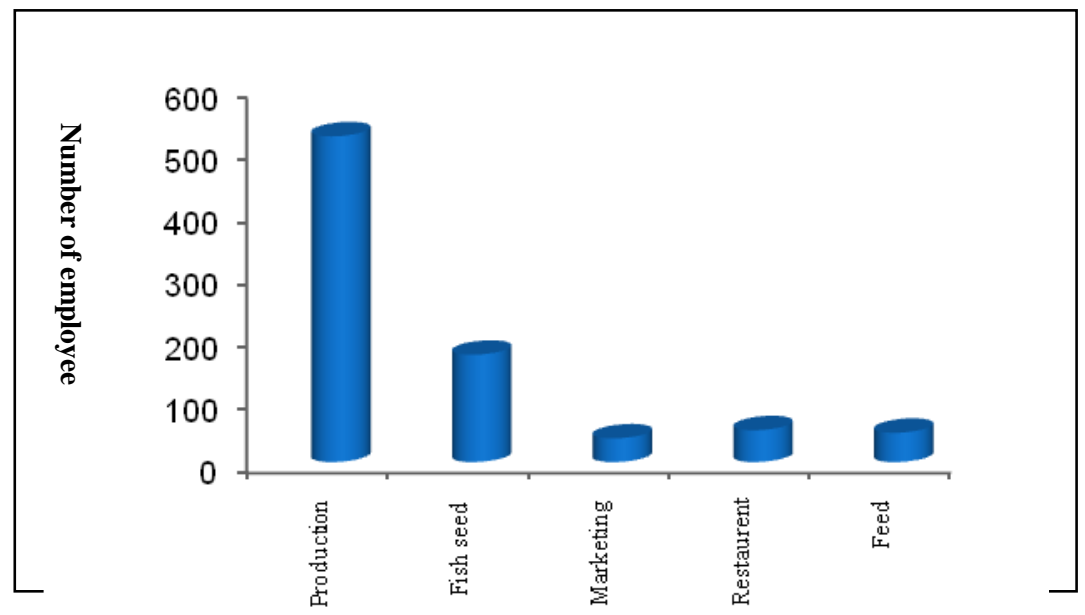

Figure 6. Number of youth full and part time employees engaged in trout related production and allied activities in Nepal.

Although the total trout production is far below than the demand and potentiality, however, value chain components of trout farming technology and allied activities have started to demonstrate its contribution in employment generation in various fields. A general survey showed that about 830 people mostly the youths are employed in trout production activities (Figure 6). Majority of 63\% involved in production, $21 \%$ in fish seed, $4 \%$ fish marketing, $6 \%$ restaurants, $6 \%$ in feed business. This trend is suggestive that trout production indeed can be helpful to generate employment and retain the youth in the agricultural sector especially on hills and mountains in the country.

\section{Challenges}

Feed insufficiency, quality and quantity

Easy availability of quality feed is one of the major constraints for the rapid expansion of trout farming. Ensuring nutritionally rich and economically affordable feed supply mechanism for poor farmers have been important for sustainable trout aquaculture. Till now the feeds for trout cultivation are fulfilled from two sources; a) supply through fisheries research centers and b) trout farmers using small scale pellet plants. Both of these sources have limited capacity for production. Further expansion of trout farms might be hindered by the inadequate availability of quality trout feed. 


\section{Trout seed production}

Availability of suitable size of trout fry is not easy due to the ever growing demand of fish seed. Most of the new farmers need to strengthen their skill in brood management, breeding and nursing technology. Moreover, limited government setups (trout hatcheries) and poor accessibility to trout farming sites (poor road network, difficult physiography) can be considered as additional barrier for enhancing commercial trout farming.

\section{Disease}

Occurrence of trout diseases, especially of feed and nutrition origin have been one of the major challenges for trout farming in Nepal. Besides that, bacterial and fungal diseases (e.g. Columnaris and that cause tail and fin rot), gill diseases and abdominal dropsy are some of the commonly occurring ones.

\section{Inadequate skilled human resource}

Sustainability of trout farming needs skilled research, extension and academic human resource networks similar to the need to other agricultural commodities. Though, a bunch of scientists, farmers, extension officers and few technicians have been trained on trout farming. More skilled human resource would be prerequisite to sustain the ever increasing trout farmers and production.

\section{Weak extension mechanism}

At present rainbow trout farming extension is being carried out by general agriculture extension agents without having a proper knowledge of trout farming. These extension agents may not be able to provide effective technical services to trout farmers in hills. Mandatorily fisheries extension services are not available in districts having high potential for trout cultivation.

\section{Post harvest and market linkage}

Present trout marketing and post harvest management is not sufficient to support the production enhancement of trout. There is a need to strengthen the market linkages and post harvest technological development for rainbow trout farming.

\section{Maintenance of pure line breeds}

Inbreeding is a common occurrence in aquaculture species. Thus, maintenance of pure line in research stations and farms would be a challenge. It is suggestive to put considerable efforts on maintenance of the pure line of rainbow trout.

\section{Way forward}

Rainbow trout farming in Nepal Himalaya is relatively a new practice having immense potentiality to bring a 'paradigm shift' in cold water aquaculture production as approximately $70 \%$ of total areas in Nepal are suitable with abundant pristine water resources. The present trends suggest that the farming of trout would be expanded more. However, it is likely that the current trend of commercial trout farming would not be limited to Nepal Himalaya, but expanded in most of the areas of the Trans-Himalayan countries and others (Edwards, 1990; Gopalkrishnan et al., 1999; Jindasa et al., 2005; Hasan et al., 2007). Several countries are planning to initiate and commercialize rainbow trout production (Petr, 1999). Considering the food and nutritional security, unemployment, youth migration especially from mountainous regions, more focus to utilize the cold water resources by adopting rainbow trout production in national plans are recommended for sustainable hill and mountain development. 


\section{Conclusion}

The current success further promises the wider potentiality of rainbow trout production using pristine Himalayan waters. The trout produced in the Himalayas could easily be branded as "Himalayan Rainbow trout" for domestic as well as global market. Further adoption of rainbow trout farming requires investment on quality research on feed, health management, extension network, best management practices and efficient marketing of quality products etc. In addition, if the year round seed production technologies are developed then rainbow trout has the potentiality to be one of the leading aquaculture commodities of Trans Himalayan countries.

\section{Acknowledgements}

Thanks to all staffs at Fisheries Research Division, Godawari and Fisheries Research Center, Trishuli for providing useful information on trout farming in Nepal. Fund for this study was available from Nepal Agricultural Research Council. Thanks to Directorate of Fisheries Development for their cooperation in various studies on rainbow trout cultivation. Authorities of Ministry of Agricultural Development are gratefully acknowledged for their support.

\section{References}

Edwards, D. 1990. Report prepared for the project Rainbow Trout Culture in Afghanistan. FI: DP/AFG/86/013, p. 7. http://www.fao.org/docrep/field/003/U2214E/U2214E00.htm

Elizabeth, S.R., T.B. Frederic, T.G. Gaylord,' J. Paterson, M.K. Petersen \& W.M. Sealey. 2014. Investigation of the effects of dietary protein source on copper and zinc bioavailability in fishmeal and plant-based diets for rainbow trout. Aquaculture 432: 97-105. http://dx. doi.org/10.1016/j.aquaculture.2014.04.029

Gopalkrishnan, A., K.K. Lal, \& A.G. Ponniah. 1999. Conservation of Nilgiri Rainbow trout in India, NAGA: Aquaculture section of the network of tropical aquaculture and fisheries professionals. The ICLARM quarterly 22(3): 1-4.

Gurung, T.B. \& S.R. Basnet. 2003. Introduction of rainbow trout Oncorhynchus mykiss in Nepal: Constraints and prospects. Aquaculture Asia 8: 4

Gurung, T.B. 2010. Rainbow trout: precious souvenir from Japan, Milan. JICA Alumni Association of Nepal (JAAN), 37 ${ }^{\text {th }}$ Annual Issue, pp. 15-17. www.jaan.org.np

Gurung, T.B., N. Pradhan, D.M. Singh \& T.B. Thapa. 2008. Prospects of trout (Oncorhynchus mykiss) farming commercialization in relation to global context in Nepal. In: Proceedings of the workshop on "Rainbow trout farming scaling-up strategies in Nepal" (Gurung, T.B. Ed.), pp. 91-98.

Jindasa, J., A.B. Kothlawala \& B.K. Herath. 2005. Status of rainbow trout (Oncorhynchus mykiss Waldaum 1792) population after the cessation of stocking in waterways of Horton Plains, Sri Lanka. Vidyodaya Journal of Sciences 12: 9-27.

Joshi, P.L. \& L.M.W. Lofvall. 1997. Production technology and prospects of trout farming in Nepal. In: Proceedings of the National symposium on the role of fisheries and aquaculture in economic development of rural Nepal. (Swar, D.B., G.B.N. Pradhan \& L.M.F. Westland Eds.), NEFIS, pp. 27-34.

Lamsal, G.P., S.R. Basnet \& P.B. Rumba, 2008. A case study on integrated trout farming in hill terraces with other developmental activities. In: Proceedings of the workshop on "Rainbow trout farming scaling-up strategies in Nepal”, (Gurung, T.B. Ed.), pp. 115-119.

Nakagawa, U. 1998. Rainbow trout introduction in Nepal (in Japanese). Aquaculture 6: 84-86. 
Nepal, A.P., S.R. Basnet, G.P. Lamsal, P.L. Joshi \& R.M. Mulmi. 2002. Economics of rainbow trout farming in Nepal. In: Cold water fisheries in the trans-Himalayan countries (Petre, T. \& D.B. Swar Eds.). FAO Fisheries Technical Paper, Rome.

Petr, T. 1999. Fish and fisheries at higher altitudes: Asia. FAO Fisheries Technical Paper 385. 304p. http://www.fao.org/docrep/003/x2614e/x2614e00.htm

Rai, A.K., S.R. Basnet, R.C. Bhujel \& G.P. Lamsal. 2005. Rainbow trout (Oncorhynchus mykiss) culture in the Himalayan Kingdom of Nepal: A success story. Asia-Pacific Association of Agricultural Research Institutions (APAARI), FAO Regional Office for Asia and the Pacific Bangkok, Thailand

Rajbanshi, K.G. 2002. Zoogeographical distribution and the status of cold water fish in Nepal. In: Cold water fisheries in the trans-Himalayan countries (Petre, T. \& D.B. Swar Eds.). FAO Fisheries Technical Paper No. 431, Rome. pp. 221-246.

Shahrzad, B., B.K. Masoumeh \& H. Kaivan. 2013. Effects of different photoperiod regimes on growth and feed conversion rate of young Iranian and French rainbow Trout (Oncorhynchus mykiss). World Applied Science Journal 21(10): 1440-1444.

Shrestha, J. 2008. A study on business scope of rainbow trout farming in Nuwakot district. A Technical Report Submitted to Agro Enterprise Centre (AEC). Federation of Nepalese Chamber of Commerce and Industry (FFNCCI). 72p.

Swar, D.B. 2002. The status of cold water fish and fisheries in Nepal and prospects of their utilization for poverty reduction. In: Cold water fisheries in the trans-Himalayan countries (Petre, T. \& D.B. Swar Eds.). FAO Fisheries Technical Paper, FAO, Rome.

Swar, D.B. 2008. History of Rainbow trout (Oncorhynchus mykiss) introduction in Nepal. In: Proceedings of the workshop on "Rainbow trout farming scaling-up strategies in Nepal (Gurung, T.B. Ed.). pp. 21-24.

Voorhees, T.M. 2011. The potential to expand the rainbow trout (Oncorhynchus mykiss) commercial aquaculture industry in the mid-and high-hills of Nepal. Ecological Aquaculture, Dr. Barry Costa-Pierce, University of Rhode Island.

Yamada, T., M.K. Karna \& K.R. Bastola. 1998. Comparative studies on hatchability, abnormality and advance rate of rainbow trout, Onchorynchus mykiss alevins. In: Present status of fisheries research development and education in Nepal (Pradhan, B.R. Ed.). Natural Water Fisheries Development Project, Nepal Agriculture Research Council, Japan International Cooperation. 